"Mircea cel Batran" Naval Academy Scientific Bulletin, Volume XIX - 2016 - Issue 2

The journal is indexed in: PROQUEST / DOAJ / Crossref / EBSCOhost / INDEX COPERNICUS / DRJI / OAJI I JOURNAL INDEX / I2OR / SCIENCE LIBRARY INDEX / Google Scholar / Academic Keys/ ROAD Open Access I Academic Resources / Scientific Indexing Services / SCIPIO / JIFACTOR

\title{
CONSIDERATIONS REGARDING THE VON MISES STRESS DEVELOPED ON A 2000X100X4MM PLATE DURING THE IMPACT WITH A 6.2KG CYLINDRICAL BODY
}

\author{
Daniel MARASESCU ${ }^{1}$ \\ Marian RISTEA ${ }^{2}$ \\ Adrian POPA ${ }^{3}$ \\ Ionut-Cristian SCURTU ${ }^{4}$ \\ Anastase PRUIU ${ }^{5}$
}

${ }^{1} \mathrm{PhD}$ attendee, Marine Engineering and Naval Weapons Department

${ }^{2}$ Assist prof. PhD Eng. Marine Engineering and Naval Weapons Department

${ }^{3}$ Assist. prof. PhD. Eng., Marine Engineering and Naval Weapons Department

${ }^{4}$ Principal Instructor, PhD Eng. "Mircea cel Batran" Naval Academy

${ }^{5}$ Professor PhD Eng. Marine Engineering and Naval Weapons Department

Abstract: This article is illustrating several studies and analysis regarding the impact on a steel plate. The von Misses stress of $2000 \times 1000 \times 4 \mathrm{~mm}$ steel plate is particularly emphasized.

Keywords: vonMises stress, impact body, energy impact, distortion.

In this paper-work are presented several studies on a $2000 \times 1000 \times 4 \mathrm{~mm}$ steel plate.

This studies are considering the plate to be fixed on all 4 sides and a cylindrical body hits it with impact speeds from 1 to $20 \mathrm{~m} / \mathrm{s}$. Also, the standard earth gravity is considered to be active.

The studies were carried out in ANSYS 12.1. Both, plate and considered to be made from structural steel.

At the impact, the geometry is presented in below figure:

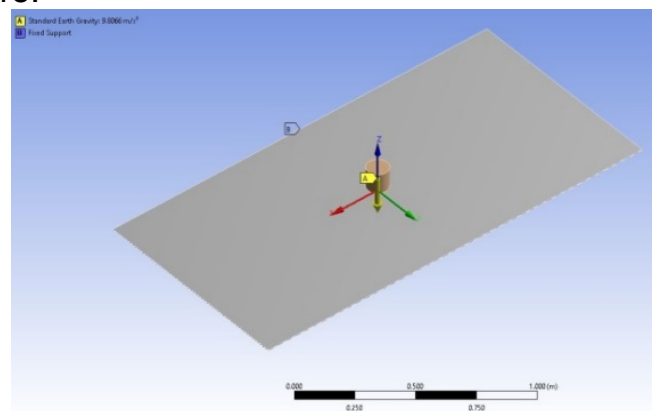

Figure 1 The geometry at the impact

Also, in Figure 1are presented the boundary conditions.

The two bodies were meshed as below:

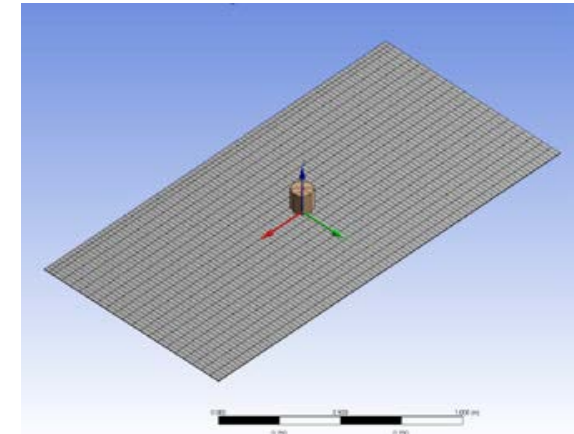

Figure 2 The meshed structure

The mesh of the plate consists in 4200 nodes and 1980 elements.

The simulations were a dynamic one, having the end time of 0.3 seconds.

Grafical results of the maximum and minimum value of von Mises stress, for each impact speed are presented below:

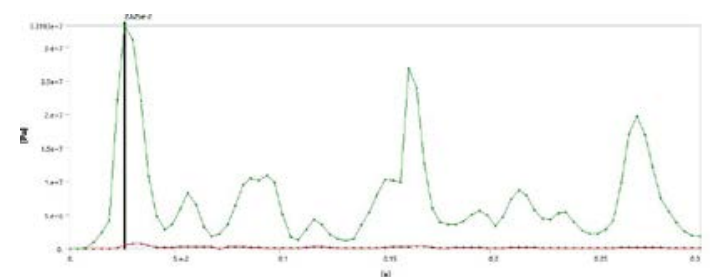

Figure 3 Maximum (green line) and minimum(red line) of the von Mises stress for $1 \mathrm{~m} / \mathrm{s}$ impact speed 
"Mircea cel Batran" Naval Academy Scientific Bulletin, Volume XIX - 2016 - Issue 2

The journal is indexed in: PROQUEST / DOAJ / Crossref / EBSCOhost / INDEX COPERNICUS / DRJI / OAJI / JOURNAL INDEX / I2OR / SCIENCE LIBRARY INDEX / Google Scholar / Academic Keys/ ROAD Open Access I Academic Resources / Scientific Indexing Services / SCIPIO I JIFACTOR

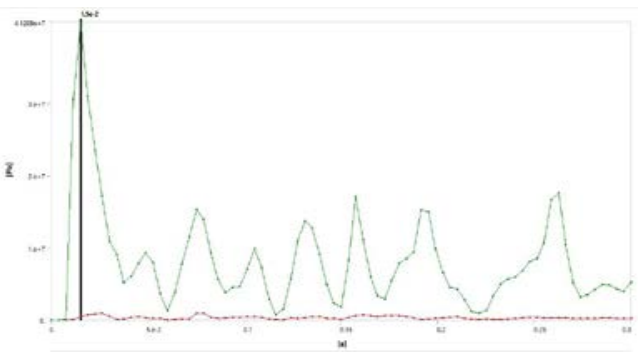

Figure 4 Maximum (green line) and minimum(red line) of the von Mises stress for $2 \mathrm{~m} / \mathrm{s}$ impact speed

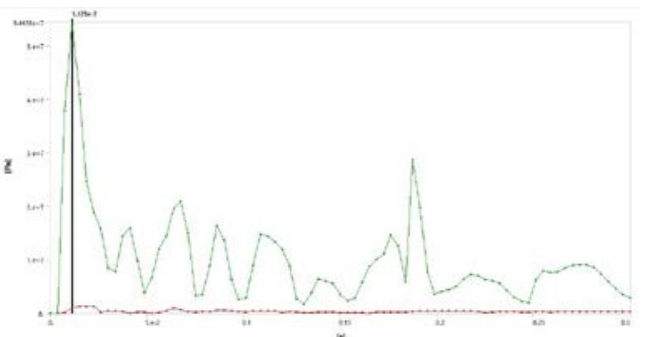

Figure 5 Maximum (green line) and minimum(red line) of the von Mises stress for $3 \mathrm{~m} / \mathrm{s}$ impact speed

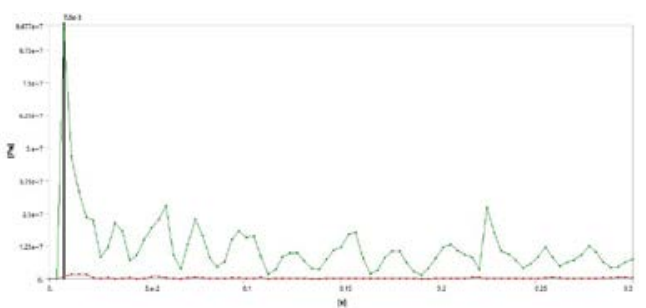

Figure 6 Maximum (green line) and minimum(red line) of the von Mises stress for $4 \mathrm{~m} / \mathrm{s}$ impact speed

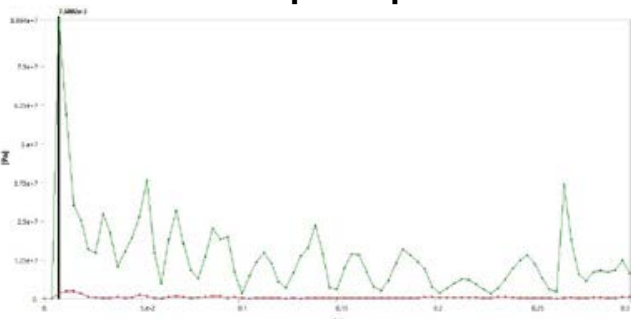

Figure 7 Maximum (green line) and minimum(red line) of the von Mises stress for $5 \mathrm{~m} / \mathrm{s}$ impact speed

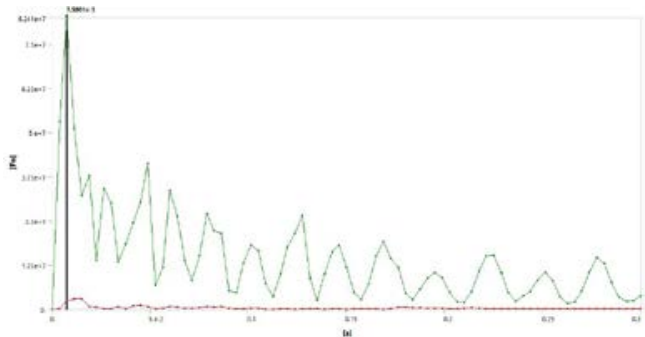

Figure 8 Maximum (green line) and minimum(red line) of the von Mises stress for $6 \mathrm{~m} / \mathrm{s}$ impact speed

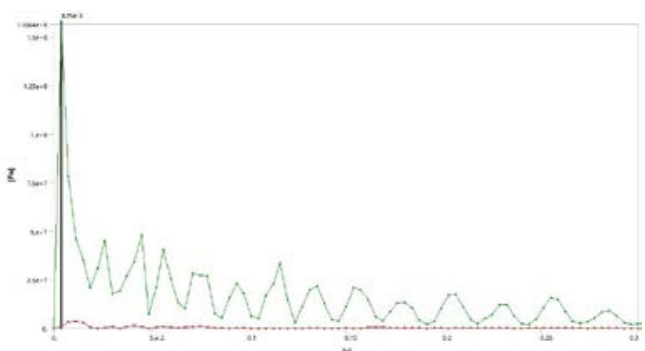

Figure 9 Maximum (green line) and minimum (red line) of the von Mises stress for $7 \mathrm{~m} / \mathrm{s}$ impact speed

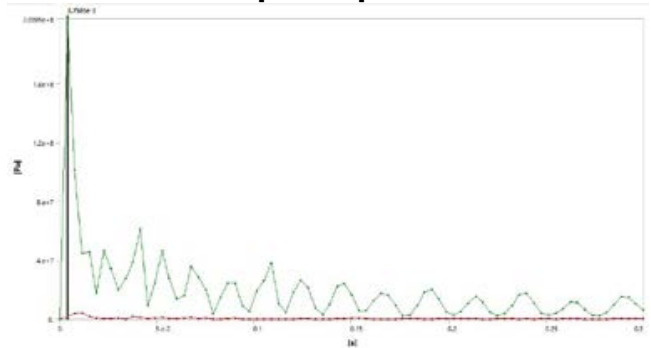

Figure 10 Maximum (green line) and minimum (red line) of the von Mises stress for $8 \mathrm{~m} / \mathrm{s}$ impact speed

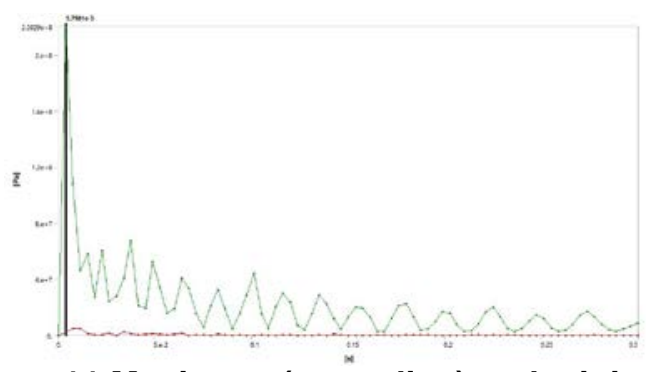

Figure 11 Maximum (green line) and minimum (red line) of the von Mises stress for $9 \mathrm{~m} / \mathrm{s}$ impact speed 
"Mircea cel Batran" Naval Academy Scientific Bulletin, Volume XIX - 2016 - Issue 2

The journal is indexed in: PROQUEST / DOAJ / Crossref / EBSCOhost / INDEX COPERNICUS / DRJI / OAJI / JOURNAL INDEX / I2OR / SCIENCE LIBRARY INDEX / Google Scholar / Academic Keys/ ROAD Open Access I Academic Resources / Scientific Indexing Services / SCIPIO / JIFACTOR

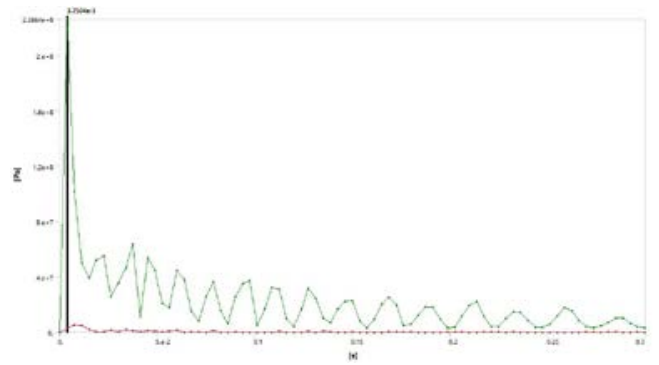

Figure 12 Maximum (green line) and minimum (red line) of the von Mises stress for $10 \mathrm{~m} / \mathrm{s}$ impact speed

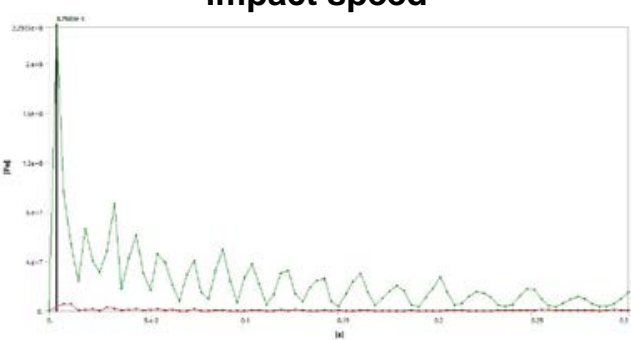

Figure 13 Maximum (green line) and minimum (red line) of the von Mises stress for $11 \mathrm{~m} / \mathrm{s}$ impact speed

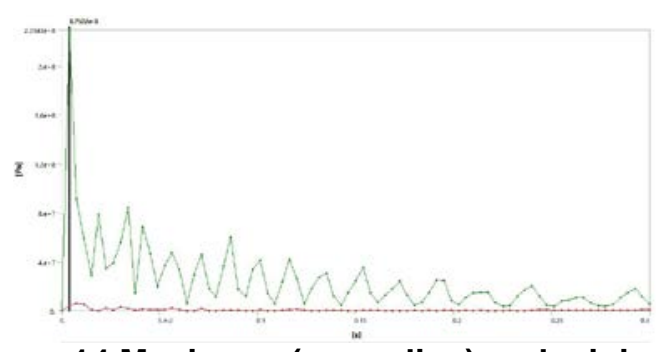

Figure 14 Maximum (green line) and minimum (red line) of the von Mises stress for $12 \mathrm{~m} / \mathrm{s}$ impact speed

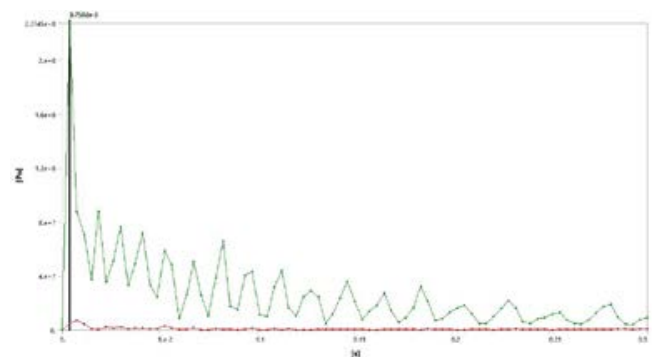

Figure 15 Maximum (green line) and minimum (red line) of the von Mises stress for $13 \mathrm{~m} / \mathrm{s}$ impact speed

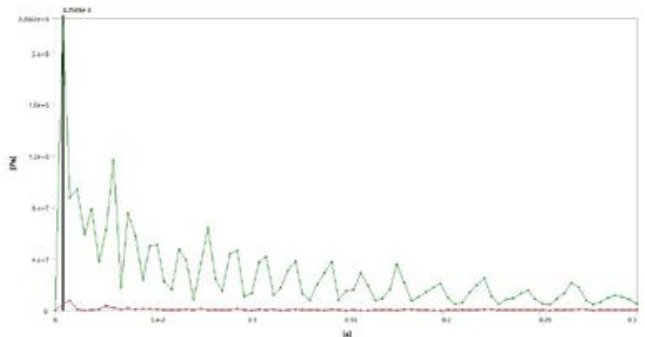

Figure 16 Maximum (green line) and minimum (red line) of the von Mises stress for $14 \mathrm{~m} / \mathrm{s}$ impact speed

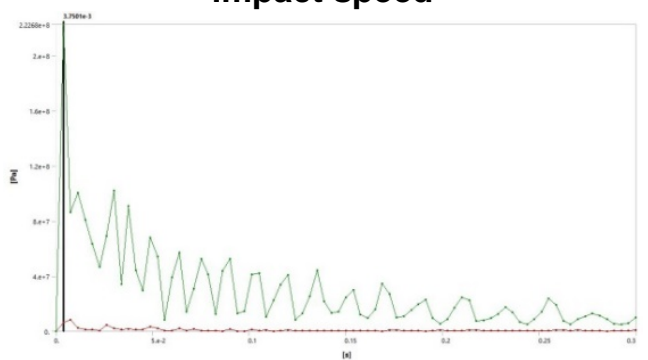

Figure 17 Maximum (green line) and minimum (red line) of the von Mises stress for $15 \mathrm{~m} / \mathrm{s}$ impact speed

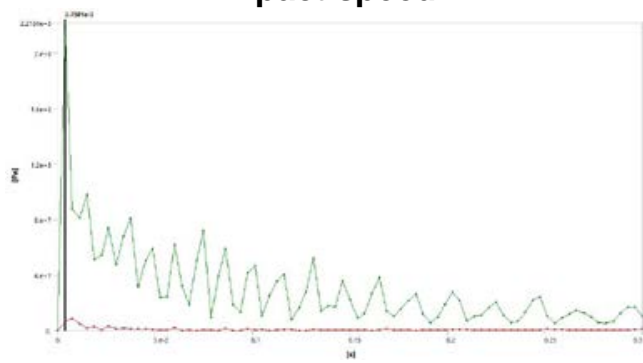

Figure 18 Maximum (green line) and minimum (red line) of the von Mises stress for $16 \mathrm{~m} / \mathrm{s}$ impact speed

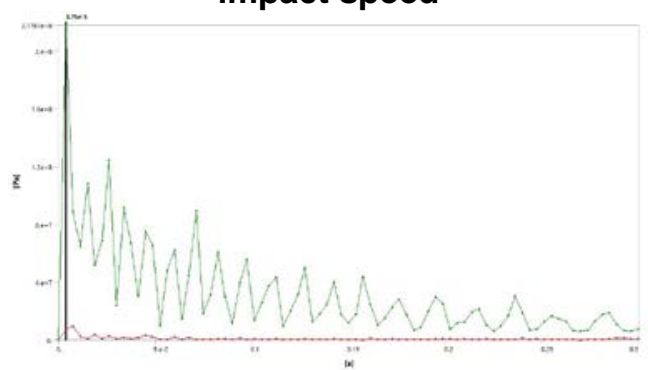

Figure 19 Maximum (green line) and minimum (red line) of the von Mises stress for $17 \mathrm{~m} / \mathrm{s}$ impact speed 
"Mircea cel Batran" Naval Academy Scientific Bulletin, Volume XIX - 2016 - Issue 2 The journal is indexed in: PROQUEST I DOAJ / Crossref / EBSCOhost / INDEX COPERNICUS I DRJI / OAJI I JOURNAL INDEX / I2OR / SCIENCE LIBRARY INDEX / Google Scholar / Academic Keys/ ROAD Open Access I Academic Resources / Scientific Indexing Services / SCIPIO / JIFACTOR

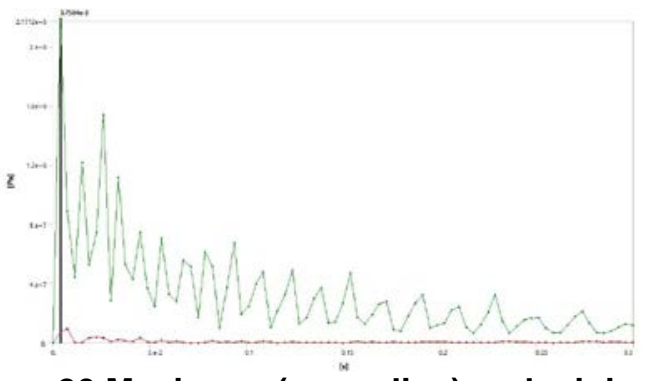

Figure 20 Maximum (green line) and minimum (red line) of the von Mises stress for $18 \mathrm{~m} / \mathrm{s}$ impact speed

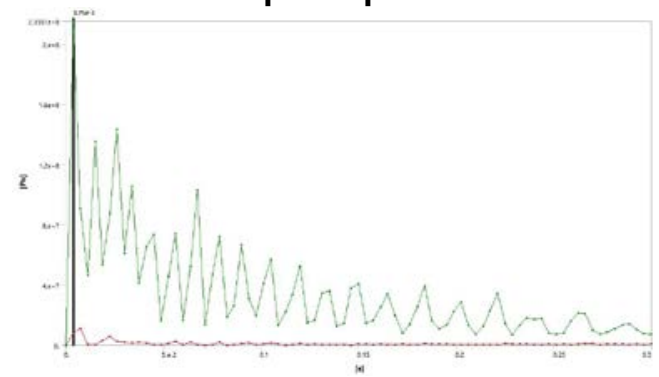

Figure 21 Maximum (green line) and minimum (red line) of the von Mises stress for $19 \mathrm{~m} / \mathrm{s}$ impact speed

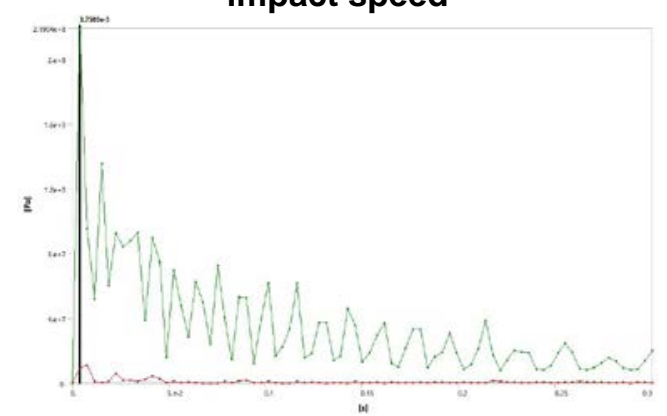

Figure 22 Maximum (green line) and minimum (red line) of the von Mises stress for $20 \mathrm{~m} / \mathrm{s}$ impact speed

Maximum values of the von Mises stress are presented in below table:

Table 1 Maximum values of the von Mises stress

\begin{tabular}{|l|l|l|l|}
\hline $\begin{array}{l}\text { Speed } \\
{[\mathrm{m} / \mathrm{s}]}\end{array}$ & $\begin{array}{l}\text { von Mises } \\
\text { stress } \\
{\left[\mathrm{N} / \mathrm{mm}^{2}\right]}\end{array}$ & $\begin{array}{l}\text { Speed } \\
{[\mathrm{m} / \mathrm{s}]}\end{array}$ & $\begin{array}{l}\text { von Mises } \\
\text { stress } \\
{\left[\mathrm{N} / \mathrm{mm}^{2}\right]}\end{array}$ \\
\hline 1 & 33.19 & 11 & 229.35 \\
\hline 2 & 41.209 & 12 & 229.43 \\
\hline 3 & 54.438 & 13 & 227.45 \\
\hline 4 & 96.77 & 14 & 226.63 \\
\hline 5 & 89.94 & 15 & 222.68 \\
\hline 6 & 82.41 & 16 & 221.84 \\
\hline 7 & 156.64 & 17 & 217.81 \\
\hline 8 & 203.95 & 18 & 217.12 \\
\hline 9 & 220.29 & 19 & 215.51 \\
\hline 10 & 226.64 & 20 & 219.04 \\
\hline
\end{tabular}

Grafically, the maximum values of the von Mises stress are presented below:

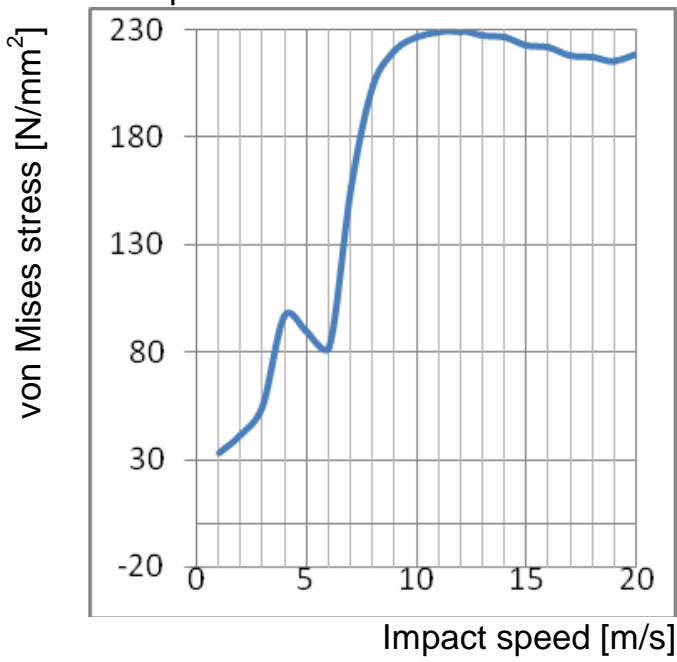

Figure 23 Maximum values of the von Mises stress for different impact speed

As it can be seen, this variation is curious. To understand the phenomenon it is necessary to study the repartition diagram for the von Mises stress.

The diagrams are presented below:

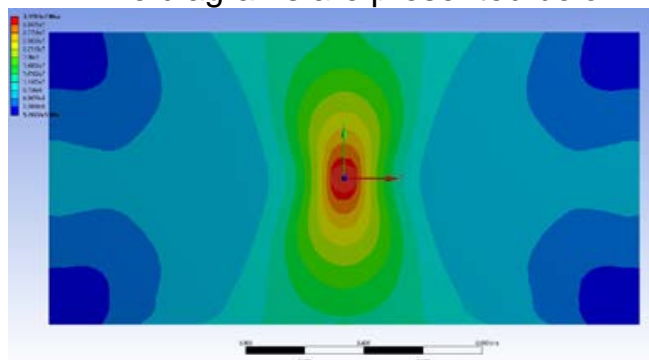

Figure 24 Repartition diagram of von Mises stress for $1 \mathrm{~m} / \mathrm{s}$ impact speed when its maximum value is reached

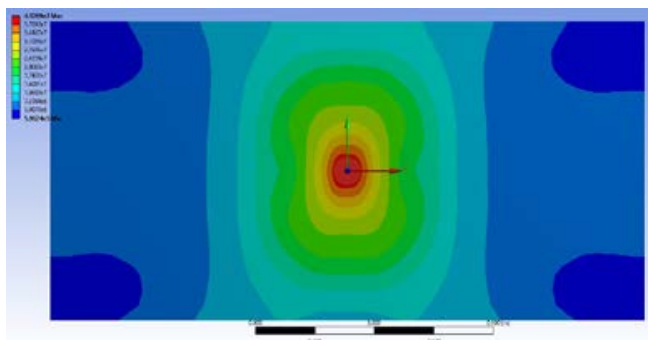

Figure 25 Repartition diagram of von Mises stress for $2 \mathrm{~m} / \mathrm{s}$ impact speed when its maximum value is reached 
"Mircea cel Batran" Naval Academy Scientific Bulletin, Volume XIX - 2016 - Issue 2 The journal is indexed in: PROQUEST / DOAJ / Crossref / EBSCOhost / INDEX COPERNICUS / DRJI / OAJI I JOURNAL INDEX I I2OR / SCIENCE LIBRARY INDEX / Google Scholar / Academic Keys/ ROAD Open Access I Academic Resources / Scientific Indexing Services / SCIPIO / JIFACTOR

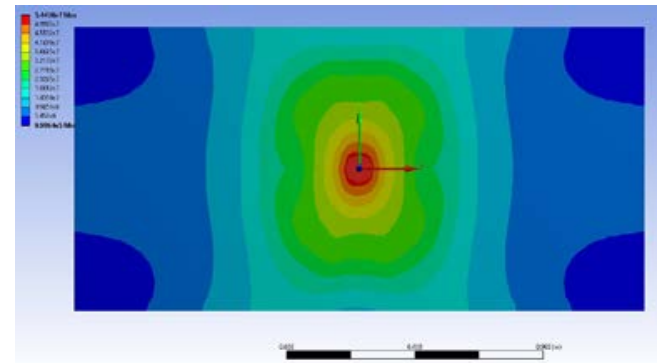

Figure 26 Repartition diagram of von Mises stress for $3 \mathrm{~m} / \mathrm{s}$ impact speed when its maximum value is reached

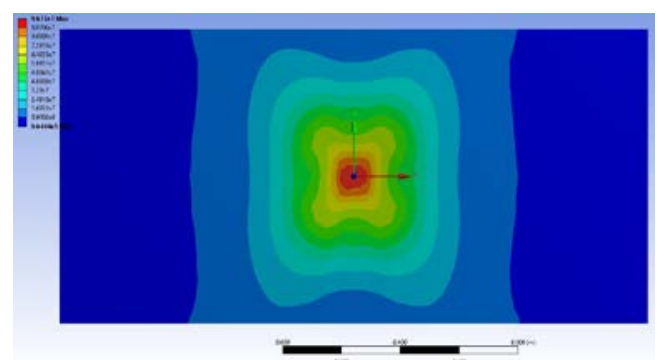

Figure 27 Repartition diagram of von Mises stress for $4 \mathrm{~m} / \mathrm{s}$ impact speed when its maximum value is reached

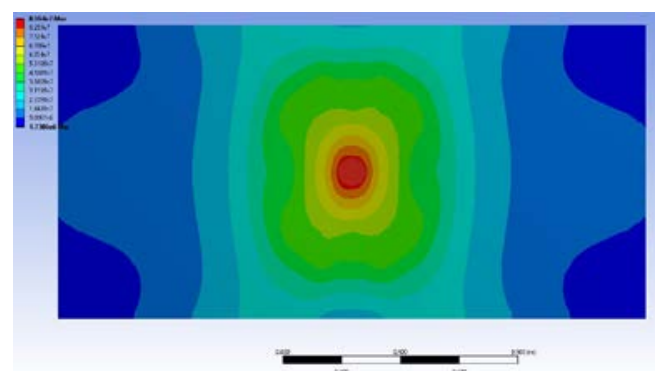

Figure 28 Repartition diagram of von Mises stress for $5 \mathrm{~m} / \mathrm{s}$ impact speed when its maximum value is reached

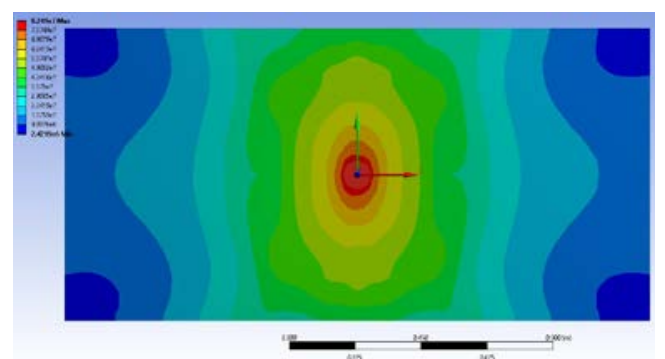

Figure 29 Repartition diagram of von Mises stress for $6 \mathrm{~m} / \mathrm{s}$ impact speed when its maximum value is reached

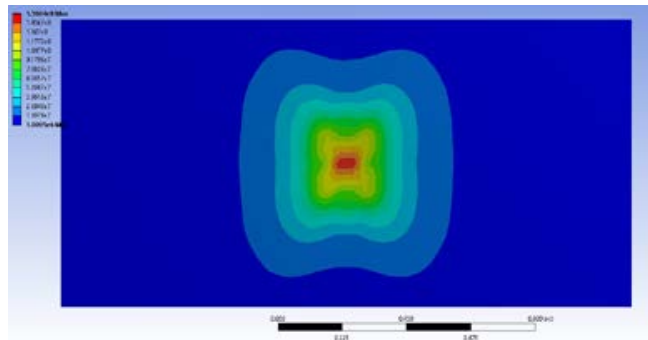

Figure 30 Repartition diagram of von Mises stress for $7 \mathrm{~m} / \mathrm{s}$ impact speed when its maximum value is reached

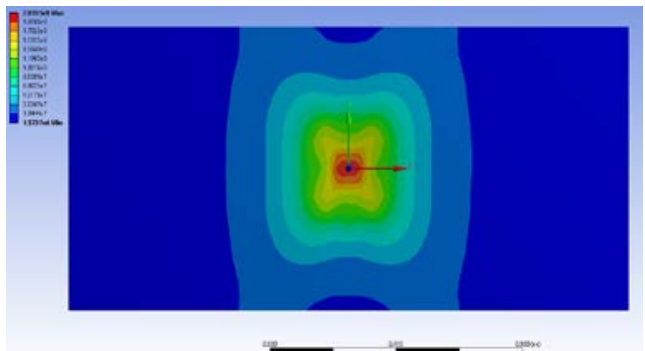

Figure 31 Repartition diagram of von Mises stress for $8 \mathrm{~m} / \mathrm{s}$ impact speed when its maximum value is reached

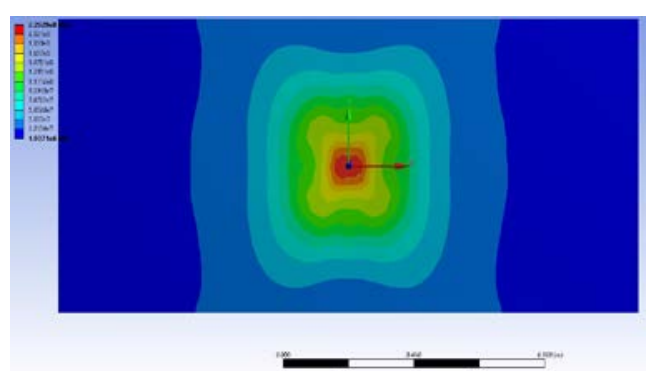

Figure 32 Repartition diagram of von Mises stress for $9 \mathrm{~m} / \mathrm{s}$ impact speed when its maximum value is reached

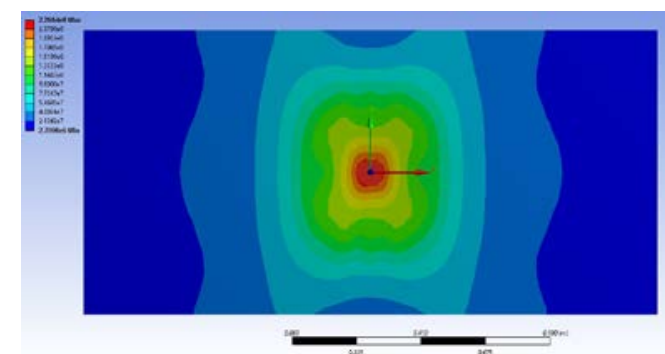

Figure 33 Repartition diagram of von Mises stress for $10 \mathrm{~m} / \mathrm{s}$ impact speed when its maximum value is reached 
"Mircea cel Batran" Naval Academy Scientific Bulletin, Volume XIX - 2016 - Issue 2 The journal is indexed in: PROQUEST / DOAJ / Crossref / EBSCOhost / INDEX COPERNICUS / DRJI / OAJI I JOURNAL INDEX I I2OR / SCIENCE LIBRARY INDEX / Google Scholar / Academic Keys/ ROAD Open Access I Academic Resources / Scientific Indexing Services / SCIPIO / JIFACTOR

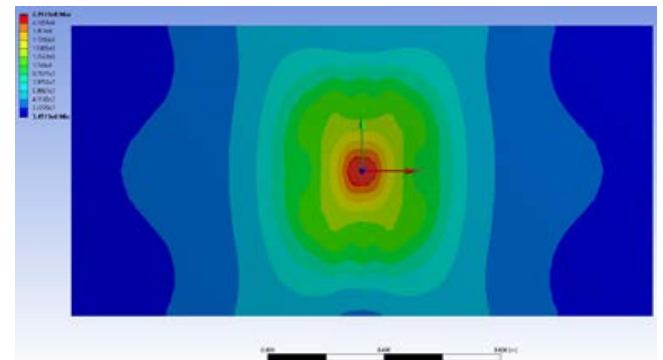

Figure 34 Repartition diagram of von Mises stress for $11 \mathrm{~m} / \mathrm{s}$ impact speed when its maximum value is reached

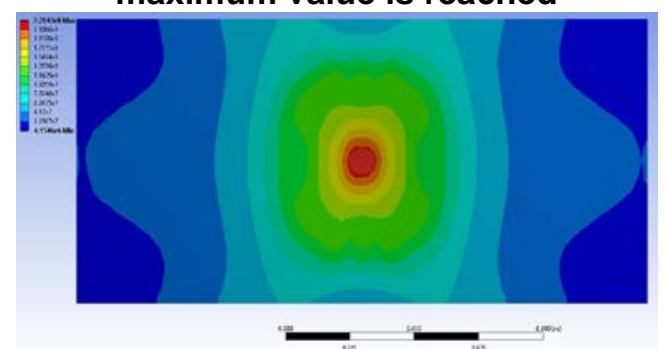

Figure 35 Repartition diagram of von Mises stress for $12 \mathrm{~m} / \mathrm{s}$ impact speed when its maximum value is reached

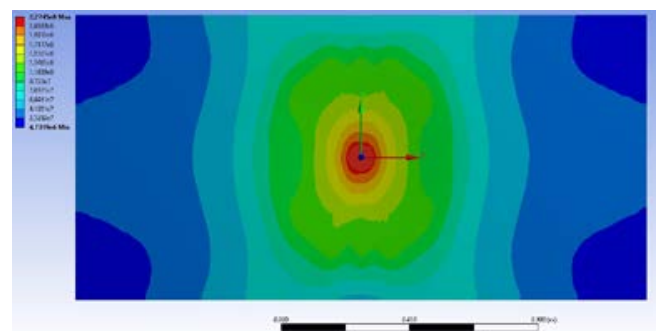

Figure 36 Repartition diagram of von Mises stress for $13 \mathrm{~m} / \mathrm{s}$ impact speed when its maximum value is reached

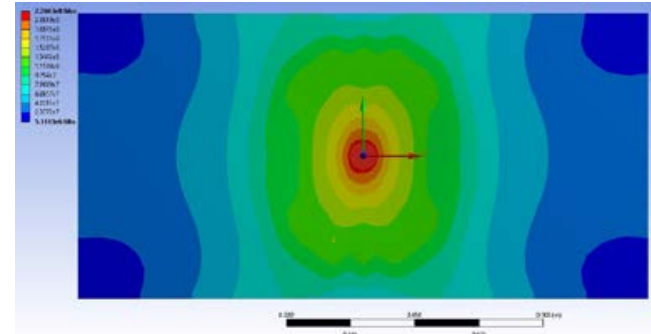

Figure 37 Repartition diagram of von Mises stress for $14 \mathrm{~m} / \mathrm{s}$ impact speed when its maximum value is reached

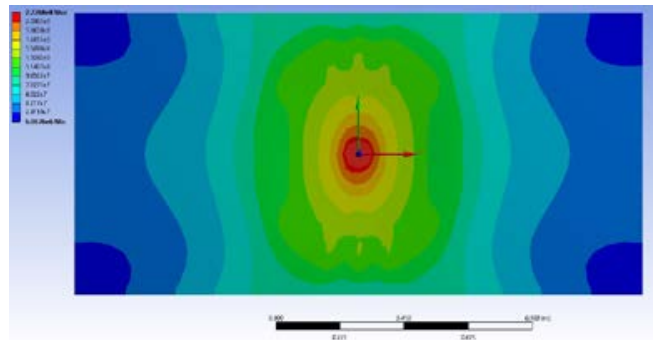

Figure 38 Repartition diagram of von Mises stress for $15 \mathrm{~m} / \mathrm{s}$ impact speed when its maximum value is reached

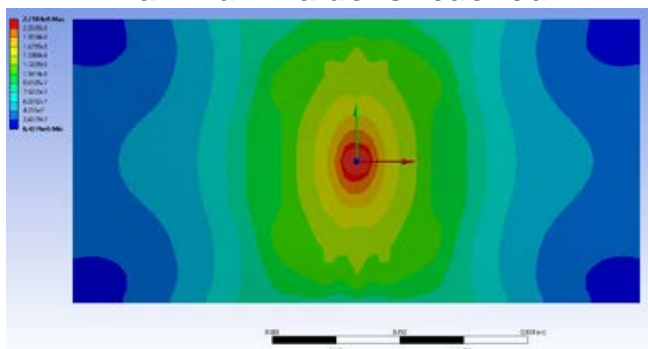

Figure 39 Repartition diagram of von Mises stress for $16 \mathrm{~m} / \mathrm{s}$ impact speed when its maximum value is reached

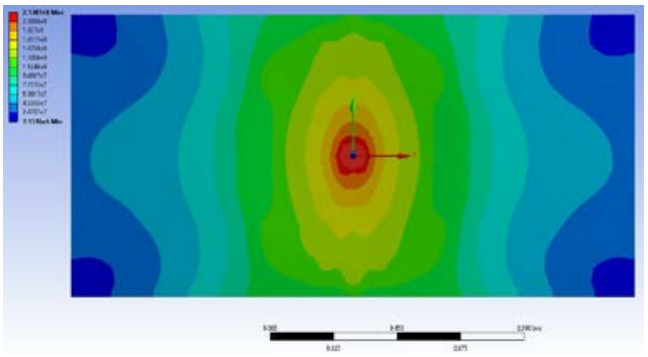

Figure 40 Repartition diagram of von Mises stress for $18 \mathrm{~m} / \mathrm{s}$ impact speed when its maximum value is reached

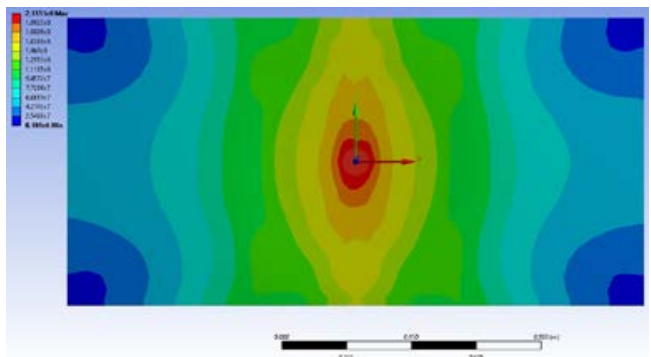

Figure 41 Repartition diagram of von Mises stress for $19 \mathrm{~m} / \mathrm{s}$ impact speed when its maximum value is reached 
"Mircea cel Batran" Naval Academy Scientific Bulletin, Volume XIX - 2016 - Issue 2 The journal is indexed in: PROQUEST / DOAJ / Crossref / EBSCOhost / INDEX COPERNICUS / DRJI / OAJI I JOURNAL INDEX I I2OR / SCIENCE LIBRARY INDEX / Google Scholar / Academic Keys/ ROAD Open Access I Academic Resources / Scientific Indexing Services / SCIPIO / JIFACTOR

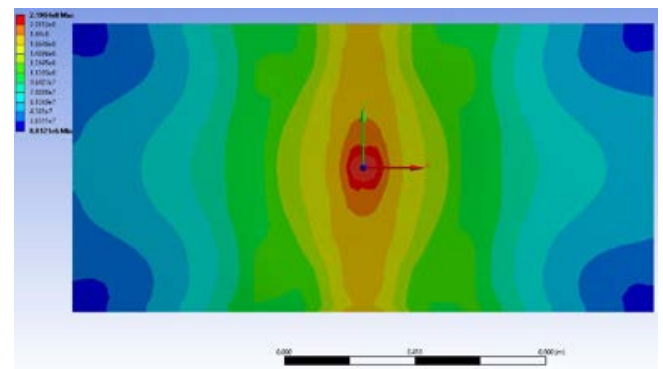

Figure 42 Repartition diagram of von Mises stress for $20 \mathrm{~m} / \mathrm{s}$ impact speed when its maximum value is reached

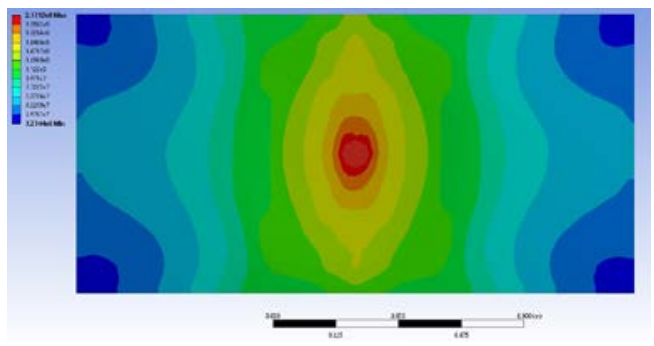

Figure 43 Repartition diagram of von Mises stress for $17 \mathrm{~m} / \mathrm{s}$ impact speed when its maximum value is reached

\section{CONCLUSIONS}

The maximum values of von Mises stress increases rapidly in the impact speed range from $1 \mathrm{~m} / \mathrm{s}$ to $8 \mathrm{~m} / \mathrm{s}$ and stays around a 220[N/mm2] for impact speeds from $9 \mathrm{~m} / \mathrm{s}$ to $20 \mathrm{~m} / \mathrm{s}$.

This is because the maximum value of von Mises stress is at the edge of the elastic interval and the impact energy dissipates on a higher area.

\section{BIBLIOGRAPHY}

[1] Ansys Workbench User Manual

[2] Huei - Huang Lee, Finite Element Simulations with Ansys Workbench 12, Schroff Development Corporation, ISBN 978-1-58503-604-2, 2010,

[3] Moaveni Saeed, Finite Element Analysis: Theory and applications with Ansys, 3rd edition, ISBN978-0-13189080-0, 2008

[4] O.C. Zienkiewicz, R.L. Taylor, The Finite Element Method for Solid and Structural Mechanics, 6th Edition, ISBN 0-7506-6321-9, 2005 